\title{
アレルギー性鼻炎発症に関与する 細胞内シグナルを標的とした治療戦略の開発
}

水口 博之

要約：アレルギー疾患感受性遺伝子の発現レベルは 症状の重篤性と相関するため, 遺伝子発現の抑制は有 効な治療法となりうる. 我々は, ヒスタミン $\mathrm{H}_{1}$ 受容 体 (H1R) 遺伝子が花粉症の疾患感受性遺伝子である ことを証明し，その遺伝子発現がプロテインキナーゼ $\mathrm{C} \delta(\mathrm{PKC} \delta)$ シグナルを介することを明らかにした. また, 和漢薬苦参由来 H1R 遺伝子発現抑制化合物 (一)マーキアインの分子薬理学的研究から, 花粉症に 対する新規創薬ターゲットとしてヒートショックプロ テイン 90（Hsp90）を同定した. Hsp90 阻害薬は鼻過 敏症モデルラットにおいて鼻粘膜 H1R 遺伝子発現え 進を抑制し症状を改善した。抗ヒスタミン薬は PKC $\delta$ シグナルを抑制し症状を改善するが, 抗ヒスタミン薬 により H1R 遺伝子発現がコントロールレベルにまで 減少しても症状は完全には改善せず, 花粉症の症状発 現に $\mathrm{PKC} \delta$ シグナルに加えて第 2 の細胞内シグナルの 関与が考えられた．スプラタストは抗ヒスタミン薬と 同様症状改善効果を示すが PKC $\delta$ シグナルを抑制せず， その症状改善効果は第 2 の細胞内シグナルの抑制によ ると考えられた。スプラタストと抗ヒスタミン薬エピ ナスチンの併用投与により, それぞれの薬物単独投与 に比べ顕著な症状改善効果が認められた。 スプラタス 卜は鼻粘膜 IL-9 遺伝子発現を強く抑制したが, エピナ スチンは IL-9 遺伝子発現を抑制せず，スプラタストが 第 2 の細胞内シグナルを介した IL-9 遺伝子発現を抑 制することが示唆された。スプラタストは RBL-2H3 細胞において NFATシグナルを介したIL-9 遺伝子発現 克進や， NFAT シグナルを介することが知られている Jurkat細胞における IL-2 遺伝子発現㐫進を抑制した。こ れらのことから，スプラタストが NFAT シグナルを抑 制することが明らかとなった. 以上の結果から, $\mathrm{PKC} \delta$
シグナルと NFAT シグナルは花粉症発症に関与する細 胞内シグナルであり，両シグナルを抑制することによ り顕著に症状を改善できることが明らかとなった。

\section{1.はじめに}

花粉症は, 現在, 国民の $30 \%$ が罹患する国民病であ り, その有病率は過去 10 年間増加の一途を辿ってい る. 現在の花粉症の治療薬は主として, 抗ヒスタミン 薬, ロイコトリエン受容体遮断薬を用いた対症療法で あり, これらは, 受容体遮断がその作用機序である. しかし, これらの効果は部分的であり, 我々が行った 鼻過敏症モデルラットを用いた研究でも, 抗ヒスタミ ン薬投与により花粉症症状は拉よそ $60 \%$ しか改善さ れなかった(1). 近年, ステロイド点鼻薬による治療 も盛んに行われているが, その作用機序や長期投与に おける副作用に対して不明な点が多い. また, スギ花 粉を用いた舌下療法は医師のモニタリングが必須であ り, 有効な効果が得られるまで数年間治療を続けなけ ればならず患者への負担が大きい，以上のことから， 花粉症の高度の症状改善を達成するため, 既存の治療 薬と異なる薬理機構を持つ治療薬の開発が望まれて いる.

我々は, 花粉症が遺伝子の異常発現を伴う多因子疾 患であると捉え, 遺伝子発現レベルが症状の重篤性に 大きく関わる疾患感受性遺伝子に着目し, その遺伝子 発現立進に寄与する細胞内シグナル分子を治療ター ゲットとし, 天然物由来シグナル抑制化合物により花 粉症に扔いて異常に立進した遺伝子発現を抑制し正常 レベルに戻すことで花粉症症状の改善を試みている (図1).

キーワード : 疾患感受性遺伝子, PKC $\delta$ シグナル, Hsp90, NFAT シグナル, 天然医薬

徳島大学大学院 医歯薬学研究部 分子情報薬理学分野 ( ₹770-8505 徳島県徳島市庄町 1-78-1)

E-mail: guchi003@tokushima-u.ac.jp 原稿受領日：2017 年 7 月 21 日，依頼原稿

Title: Development of therapeutic strategy target for intracellular signaling molecules responsible for the pathogenesis of allergic diseases Author: Hiroyuki Mizuguchi 
(A)

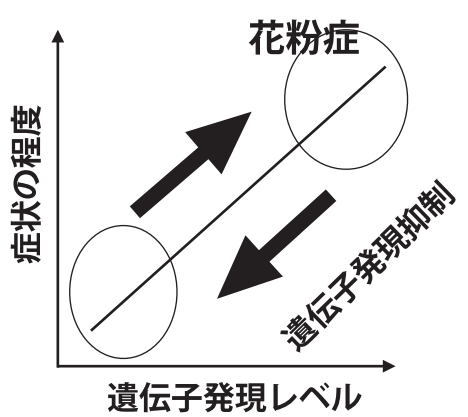

(B)

正常

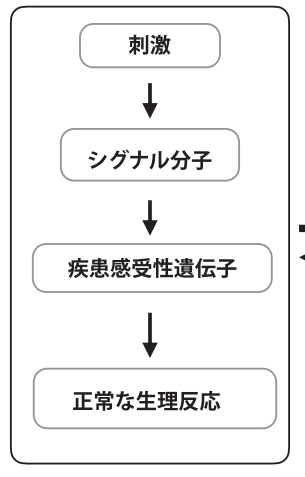

花粉症

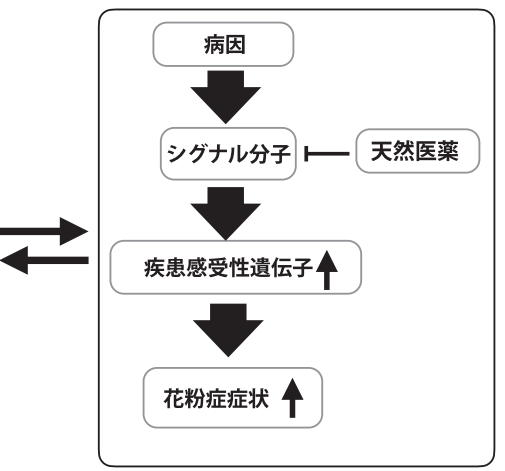

図 1 研究のストラテジー

花粉症では遺伝子発現しベルが症状の重篤性と相関する疾患感受性遺伝子の遺伝子発現が異常にえ進していると考えられる $(A)$. 天然医薬に より疾患感受性遺伝子発現シグナルを抑制し，遺伝子発現レベルを是正することで症状の改善を試みる（B).

\section{2. 疾患感受性遺伝子としてのヒスタミン $\mathrm{H}_{1}$ 受容体 (H1R) 遺伝子}

ヒスタミンは即時型アレルギー反応における主要ケ ミカルメデイエーターであり，その作用は主として G タンパク質共役型受容体（GPCR）である H1R 介し て起こる。一般に，GPCRはアゴニストの反復投与に よりダウンレギュレーションを受けるが, これは, 細 胞内に必要以上の過剰なシグナルを入れないという合 目的的な防御機構である。これに対して, 我々は, H1Rがヒスタミン刺激によりアップレギュレーショ ンを受け，プロテインキナーゼ $\mathrm{C} \delta(\mathrm{PKC} \delta)$ シグナル を介して H1R 遺伝子の発現が立進することを見出し た (2).このヒスタミンによる H1R 遺伝子アップレ ギュレーションは, アレルギー反応において発作誘発 により放出されたヒスタミンが標的細胞において $H 1 R$ 発現量を増加させ自身のヒスタミンに対する感 受性を高め, より重度な症状を引き起こすというアレ ルギー増悪化の機構であると考えられた (3).また, H1R 介するシグナルの強さは H1R 発現レベルに依 存する (4) こと, アレルギー患者では, H1R 遺伝子発 現が立進している (5) ことから, H1Rはシグナル伝達 の律速分子であり H1R 遺伝子の発現レベルがアレル ギー症状の重篤性に大きく関わると考えられ, H1R 遺 伝子がアレルギー疾患感受性遺伝子であることが強く 示唆された。 そこで, 我々は, 鼻過敏症アレルギーモ デルラットに初期療法を模して抗ヒスタミン薬を長期 投与し, アレルギー症状と H1R 遺伝子発現への影響を 検討した. その結果，抗ヒスタミン薬の長期投与によ り症状が改善し, H1R 遺伝子発現量も有意に減少する ことが明らかとなった(1).さらに，スギ花粉症患者
に初期療法を行い鼻炎症状と鼻粘膜 H1R 遺伝子発現 レベルとの関連について検討し, 鼻炎症状と H1R 遺伝 子発現レベルが正に相関すること, 初期療法群では鼻 炎症状も H1R 遺伝子発現量も有意に減少していること が明らかとなった (図 2A) (6).さらに, このことは, 花 粉暴露室を利用した研究によっても証明され（図 2B） (7), H1R 遺伝子が花粉症の疾患感受性遺伝子である ことが明らかとなった. 我々は, 天然医薬にH1R遺伝 子発現抑制成分を見出し, 緑茶葉, 和漢薬苦参及び, 桑葉に含まれる H1R 遺伝子発現化合物としてエピガ ロカテキンガレート, ケルセチン及び $($-)マーキアイ ンを同定した(8-10). これらの化合物は鼻過敏症モデ ルラットにおいて鼻炎症状を改善し, 鼻粘膜 H1R 遺伝 子発現立進も抑制していた. 以上のことから, H1R 遺 伝子発現シグナルの抑制が花粉症治療戦略として有効 であることが明らかとなった。

\section{H1R 遺伝子発現シグナル分子ヒートショック タンパク質 90 (Hsp90) の発見}

$($ - ) マーキアインの H1R 遺伝子発現抑制の分子機 構を明らかにするため, (-)マーキアインの結合タン パク質の同定を試みた。（一)マーキアインは $\mathrm{PKC} \delta$ の 活性化に必須である $\mathrm{Tyr}^{311}$ のリン酸化を抑制するが $\operatorname{PKC} \delta$ のキナーゼ活性は阻害しないことから, PKC $\delta$ 以外に標的タンパク質が存在することが示唆された. 一般に，トリプトファン残基を含むタンパク質におい て基質や阻害薬などの結合によるコンフォメーション 変化に伴い内在性トリプトファン残基の蛍光が変化す ることが知られている $(11)$. そこで, これを利用し, (一)マーキアイン結合タンパク質の同定を試みた. HeLa 細胞抽出液をイオン交換クロマトグラフィーに 
(A)

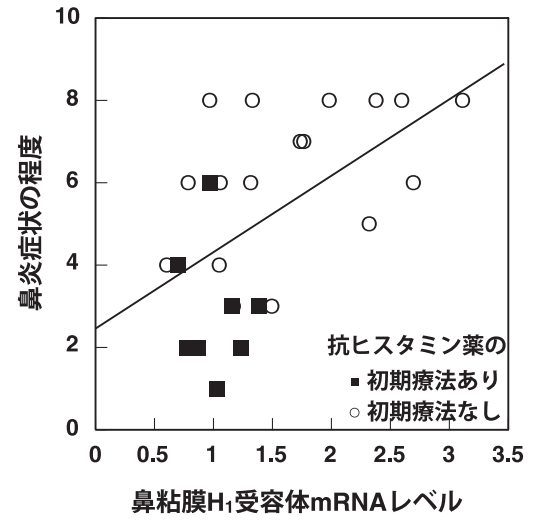

(B)

(a)
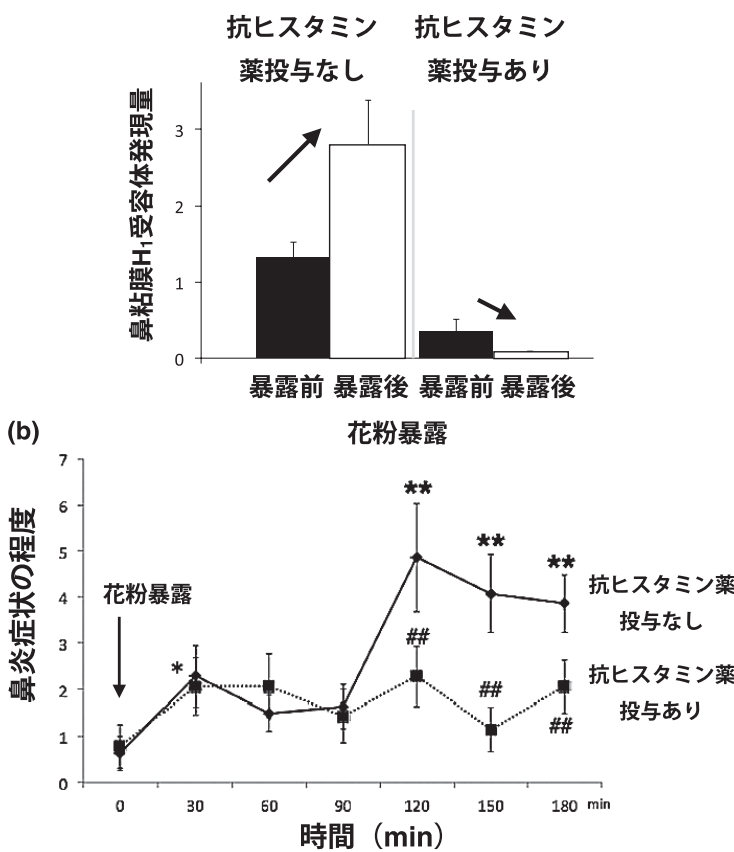

図 2 ヒスタミン $\mathrm{H}_{1}$ 受容体 $(\mathrm{H} 1 \mathrm{R})$ 遺伝子は花粉症の疾患感受性遺伝子である

(A) 花粉症患者における抗ヒスタミン薬の初期療法の鼻炎症状および H1R 遺伝子発現への影響：H1R 遺伝子発現レベルと鼻炎症状は正に相関 した. 抗ヒスタミン薬の初期療法 ( $)$ により初期療法を行わない群 $(O)$ に比較して鼻炎症状が改善しHIR 遺伝子発現しベルも減少した（文 献 6 より改变). (B) 花粉暴露実験：(a) 抗ヒスタミン薬無処置群では花粉暴露により H1R 遺伝子発現が亢進した. 抗ヒスタミン処置群では, 花粉暴露前にすでにHIR 遺伝子発現が減少していたが花粉暴露後も遺伝子発現は減少したままであった. (b) 抗ヒス夕ミン処置群 (口) では, 花粉暴露後も症状はほとんど現れなかった. データは平均士S.D. ${ }^{*} P<0.05,{ }^{*} P<0.01$ vs. 抗ヒスタミン未処置 + 花粉暴露前, ${ }^{*} P<0.01$ VS. 抗ヒスタミン薬処置+花粉暴露前 $(n=14)$ (文献 7 より改变).

(A)

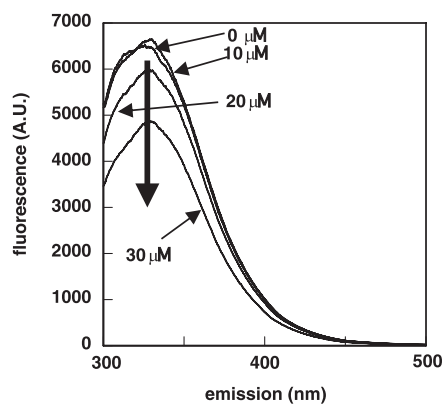

(B)

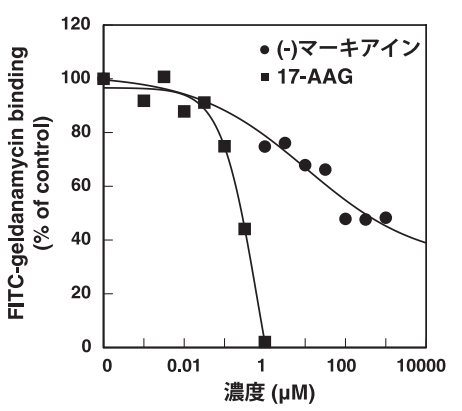

(C)

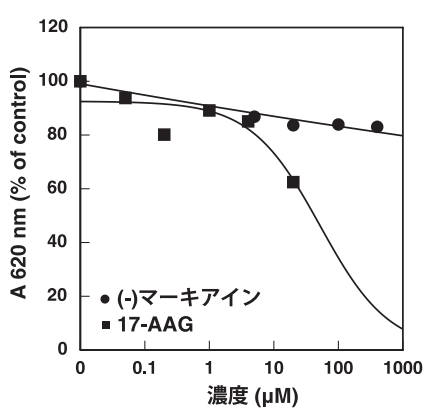

図 3 (一)マーキアイン結合タンパク質の同定

（A）蛍光クエンチング実験：Hsp90 の内在性トリプトファンに由来する蛍光は（一)マーキアインの Hsp90への結合に伴し減少した.（B）ゲ ルダナマイシン競合試験：(）マーキアインはゲルダナマイシンの Hsp90への結合に競合した. (C) ATPase 活性への影響：(一)マーキアイ ンはHsp90の ATPase 活性を阻害しなかった. 17-AAG：17-(allylamino)geldanamycin ゲルダナマイシン誘導体, Hsp90 阻害薬．（文献 12 より改変)

より分画後，それぞれの画分において $(-)$ マーキアイ ンの存在下 ・ 非存在下における蛍光を測定しその変化 量の最も大きい画分についてタンパク質を SDS-PAGE にて分離し，画分に含まれるタンパク質をMS解析 により同定した. その結果, 候補タンパク質として Hsp90 が見出された. リコンビナントHsp90 の蛍光

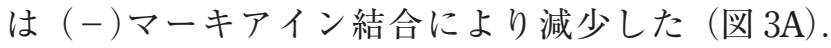

Hsp90 はそのクライアントタンパク質との結合に ATPを必要とし, Hsp90 阻害薬ゲルダナマイシンは Hsp90 の ATP 結合部位に結合することでHsp90 の活 性を阻害する。（－）マーキアインは蛍光ラベルしたゲ ルダナマイシンの結合を弱いながらも阻害したが, Hsp90 の ATPase 活性は阻害しなかった（図 3B，C）. このことから, (-)マーキアインはゲルダナマイシン 
とは異なる様式で Hsp90 に結合することが明らかと なった。

以上の結果は Hsp90 が花粉症の新規創薬ターゲッ 卜となる可能性を示唆するが, これまでに花粉症と Hsp90 との関係についての報告はなかった。 そこで, Hsp90 阻害薬の H1R 遺伝子発現抑制及び症状改善効 果について検討した(12). その結果, Hsp90 阻害薬は, HeLa 細胞において, PMA 刺激に伴う H1R 遺伝子発現 六進を抑制することが明らかとなった（図 4A）。また， その分子機構として, PKC $\delta$ は Hsp90 のクライアント タンパク質であり, 刺激のない時には Hsp90 と結合し て存在しているが, (-)マーキアインはこのPKC $\mathrm{P} \delta$ Hsp90 の結合を阻害することが明らかとなった（図 4B). さらに，鼻過敏症モデルラットにおいて，Hsp90 阻害 薬セラストロールは, 鼻粘膜 H1R 遺伝子発現光進を抑 制するとともに鼻炎症状を改善した（図 4C)。以上の 結果から, Hsp90 阻害薬が新規花粉症治療薬として有 効であることが明らかとなった。

Hsp90 は, 細胞周期・細胞分裂・細胞生存シグナル 等に関わるさまざまな生理機能分子をクライアントタ ンパク質として結合し細胞内分子ネットワークの“八 ブ”として機能するため, Hsp90 阻害薬は細胞内シグ
ナルの異常立進により引き起こされる多くの疾患に対 して有効であると考えられるが，一方，多くのシグナ ルを一度に抑制するためその副作用も大きい，そこで, クライアントタンパク質選択性を有する Hsp90 阻害 薬が開発できれば異常充進している細胞内シグナルを 選択的に抑制でき副作用も少ないことが期待される. しかし, Hsp90 のクライアントタンパク質認識機構に ついては結合するタンパク質が多岐にわたることもあ り不明な点が多い。我々の研究デー夕は $(-)$ マーキ アインと既知 Hsp90 阻害薬では Hsp90 に対する結合 様式に違いがあることを示しており, その違いを詳細 に解析することは Hsp90 の疾患選択的創薬ドメイン を明らかにし細胞内シグナル選択的な Hsp90 阻害薬 の開発につながると考えられた。

\section{4. 第 2 の花粉症症状発現シグナルの発見}

鼻過敏症モデルラットを用いた研究から, $\mathrm{PKC} \delta$ シ グナル抑制薬である抗ヒスタミン薬の長期投与により, 鼻粘膜 H1R 遺伝子発現はコントロールレベルにまで 減少するが症状は完全には改善されなかった(1)。こ のことから, PKC $\delta$ シグナル以外の花粉症症状発現シ グナルの存在が想定された。スプラタストは Th2 サ

(A)
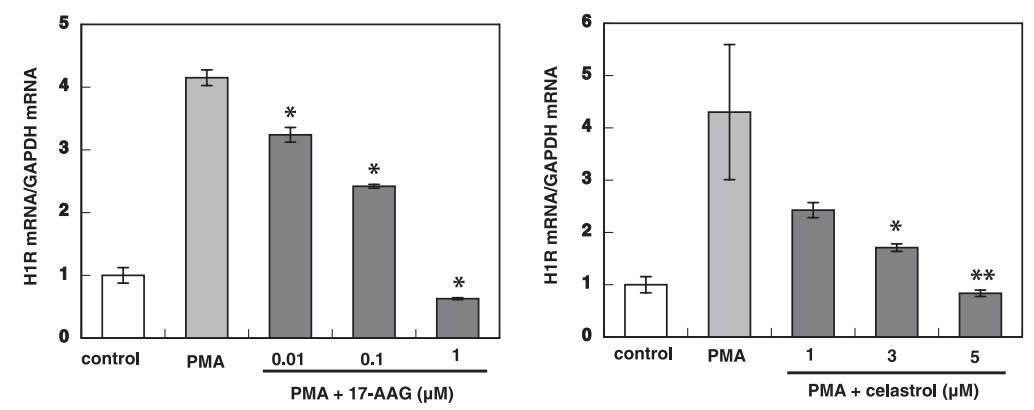

(B)

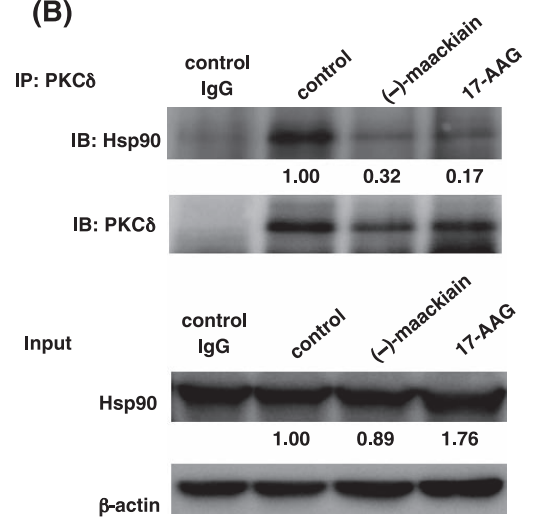

(C)
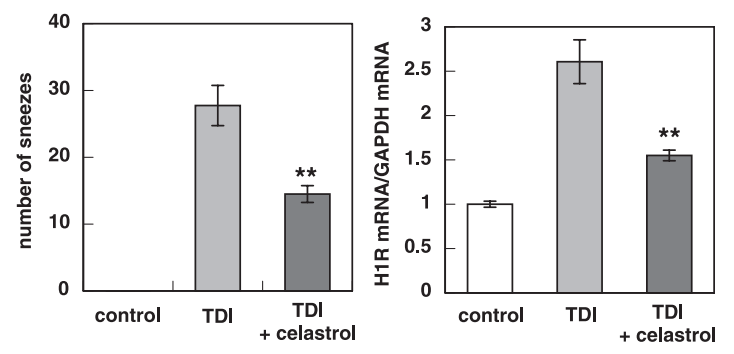

図 $4 \mathrm{Hsp90}$ 阻害薬は H1R 遺伝子発現シグナルを抑制する

(A) HeLa 細胞における Hsp90 阻害薬の PMA 刺激に伴う HiR 遺伝子発現え進に対する影響 : Hsp90 阻害薬は HeLa 細胞における PMA 刺 激に伴う HIR 遺伝子発現亢進を抑制した. デー夕は平均士S.E.M. ${ }^{*}{ }^{*} P<0.01,{ }^{*} P<0.05$ vs. PMA $(n=3)$. (B) 共免疫沈降実験：PKC $\delta$ と Hsp90 は刺激のない状態では複合体を形成していたが, (ー)マーキアイン処置により複合体は解離した. (C) 鼻過敏症モデルラットにおける Hsp90 阻害薬の症状改善効果：Hsp90 阻害薬セラストロールはモデルラットにおいて症状を改善し, 鼻粘膜 H1R 遺伝子発現も抑制した. デー 夕は平均土S.E.M. ${ }^{* *} P<0.01,{ }^{*} P<0.05$ vs. TDI $(n=4)$. (文献 12 より改変) 
イトカイン阻害薬として知られている抗アレルギー薬 である。スプラタストは鼻過敏症モデルラットにおい て抗ヒスタミン薬と同様に症状改善効果を示す。 しか し, スプラタストは HeLa細胞において PMA刺激に伴 い克進する PKC $\delta$ シグナルを介した H1R 遺伝子発現を 抑制せず(13)，スプラタストの症状改善効果は第二の 花粉症症状発現シグナルの抑制によると考えられた. そこで，スプラタストの症状改善効果の分子機構を明 らかにし, 症状発現に関与する第 2 の細胞内シグナル の同定を試みた。抗ヒスタミン薬とスプラタストを モデルラットに併用投与したところ，それぞれの薬物 の単独投与に比べ顕著な症状改善効果が認められた (図 5A) (14)。スプラタストはラット鼻粘膜の IL-4 遺 伝子及び IL-5 遺伝子の発現を抑制したが，それに加え て IL-9 遺伝子発現を強く抑制することが明らかと なった (図 5B)。一方, 抗ヒスタミン薬は IL-9 遺伝子 発現を抑制しなかった。このことは，IL-9 遺伝子発現 シグナルが第 2 の花粉症症状発現シグナルであること を強く示唆した. IL-9 は主としてTh9 細胞や肥満細胞 などから産生されるサイトカインである。また，IL-9 は ILC (自然リンパ球) 細胞や Th17 細胞, Treg 細胞 からも産生される(15)。Th9 細胞は IL-4/TGF- $\beta$ また は TGF- $\beta$ 刺激によりナイーブ T 細胞または Th2 細胞 から分化する $(16,17)$. IL-9 遺伝子発現立進に寄与す る生理活性物質についてはまだ明らかでないが，Th9 細胞において CGRP (calcitonin gene-related peptide) が PKA/NFATc2 経路を介して IL-9 を産生することが 報告されており (18), 鼻過敏症モデルラットにおいて CGRP の産生が充進していることから (19), CGRPが IL-9 の発現立進に関与する可能性が考えられる.

(A)

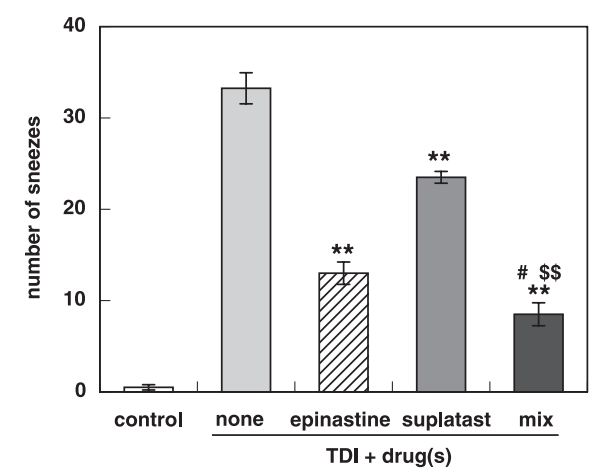

\section{NFAT シグナルは第 2 の花粉症症状発現シ グナルである}

我々は， RBL-2H3 細胞において PMA刺激に伴い IL-9 遺伝子発現が充進することを見出した (14)。この IL-9 遺伝子発現㐫進はカルシニューリン阻害薬のサイ クロスポリン A や INCA-6により抑制されることから NFAT シグナルを介することが明らかとなった（図 6A). スプラタスト及びその代謝物である M-1 はこの IL-9 遺伝子発現立進を抑制した（図 6B）。また，スプラ夕 スト及び M-1 は Jurkat 細胞における PMA /イオノマ イシン刺激に伴う NFAT シグナルを介した IL-2 遺伝子 発現光進も抑制した（図 7)。さらに，IL-2 遺伝子の NFAT 結合領域を用いてスプラタストの NFAT 転写活 性に対する影響を検討した結果, M-1 は NFATの転写 活性を抑制した（デー夕省略）．以上の結果から NFAT シグナルが第 2 の花粉症症状発現シグナルであり, ス プラタストは NFA シグナルを介した IL-9 遺伝子発現 を抑制することで鼻過敏症モデルラットにおける症状 改善効果を示すものと考えられた.

\section{2 つの花粉症症状発現シグナル抑制による 花粉症症状の改善効果}

花粉症症状発現主要細胞内シグナルとして PKC $\delta$ シ グナルと NFAT シグナルが存在することが明らかと なった（図 8)。また，抗ヒスタミン薬とスプラタスト の併用実験から両シグナルを同時に抑制することで症 状を顕著に改善できる可能性が示唆された。我々はこ れまでに徳島県特産物の阿波晚茶やレンコン抽出物中 に IL-9 遺伝子発現抑制成分の存在を見出しその有効 成分の同定に成功している。鼻過敏症モデルラットに

(B)

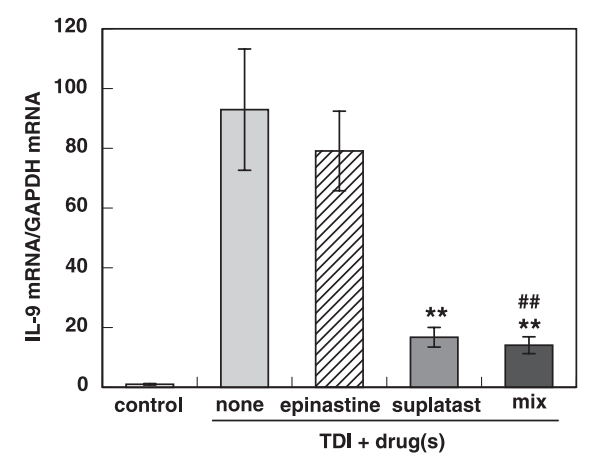

図 5 鼻過敏症モデルラットにおけるスプラタストの症状改善効果

(A) スプラタストと抗ヒスタミン薬の併用効果：抗ヒスタミン薬とスプラタストをモデルラットに併用投与したところ, それぞれの薬物の単独 投与に比べ顕著な症状改善効果が認められた. (B) スプラタストの鼻粘膜 Th2 サイトカイン遺伝子発現への影響 : スプラタストはIL-9 遺伝子 発現を強く抑制した。一方, 抗ヒスタミン薬はIL-9 遺伝子発現を抑制しなかった. データは平均土S.E.M. ${ }^{* *} P<0.01$ vs. TDI, \#P<0.05, \#\# $<0.01$ vs. エピナスチン ; ${ }^{\$} P<0.01$ vs. スプラタスト $(n=4)$. (文献 14 より改変) 
(A)

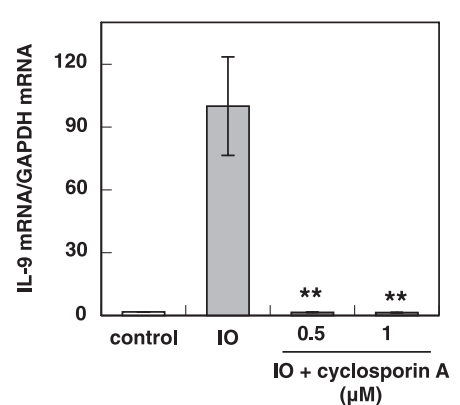

(B)

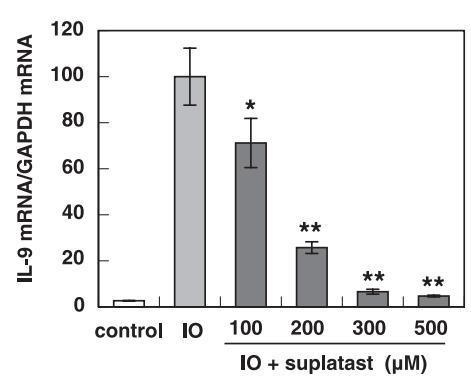

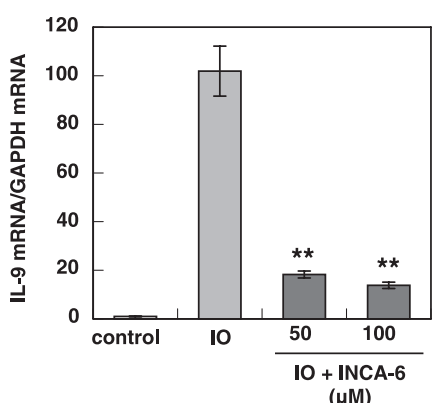

$(\mu \mathrm{M})$

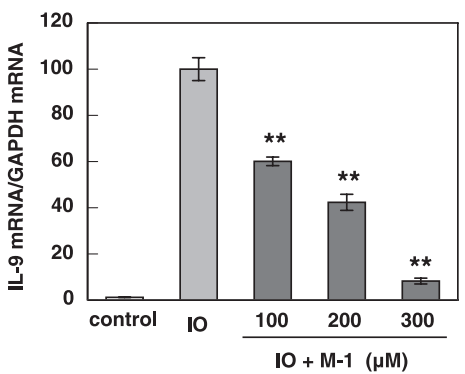

図 6 RBL-2H3 細胞における PMA 刺激に伴う IL-9 遺伝子発現六進は NFAT シグナルを介する

(A) IL-9 遺伝子発現亢進に対する NFAT シグナル阻害薬の影響：NFATシグナル阻害薬のサイクロスポリンA (CsA) およびINCA-6 はIL-9 遺伝子発現え進を抑制した. (B) IL-9 遺伝子発現亢進に対するスプラタストおよびその代謝物 M-1 の影響 : スプラタストおよび M-1 はIL-9 遺 伝子発現え進を抑制した。 IO：イオノマイシン, INCA-6：(9,10-dihydro-9,10[1',2']-benzenoanthracene-1,4-dione) カルシニューリンー NFAT 相互作用阻害薬. デー夕は平均土S.E.M. ${ }^{*} P<0.05,{ }^{* *} P<0.01$ vs. イオノマイシン $(n=3) . \quad$ 文献 14 より改変)
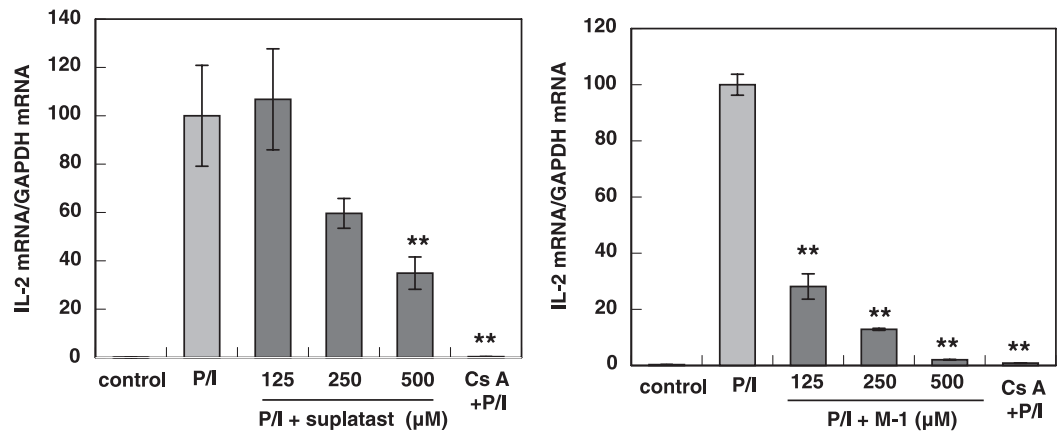

図 7 Jurkat細胞における PMA /イオノマイシン刺激に伴う NFAT シグナルを介したIL-2 遺伝子発現穴進に対するスプラタストの影響 IL-2 遺伝子発現亢進に対するスプラタストおよびその代謝物 M-1 の影響：スプラタストおよび M-1 はIL-2 遺伝子発現亢進を抑制した. P/I : PMA+イオノマイシン. データは平均士S.E.M. ${ }^{* *} P<0.01$ vs. PMA +イオノマイシン $(n=3 \sim 4) . \quad($ 文献 14 より改変)

おいて有効成分は抗ヒスタミン薬と併用投与すること によりスプラタストの場合と同様に症状が顕著に改善 されることが明らかとなった (図 9). 以上のことから も, PKC $\delta$ シグナルと NFAT シグナルの同時抑制が症 状の改善に有効であることを支持する.

\section{7. 終わりに}

これまでに我々が対象としたのはくしゃみや鼻水と いう花粉症の急性症状である. 一方, 鼻閉など花粉症 の慢性症状は好酸球増多を原因とすることが知られて いる. 我々は, 花粉症患者において鼻粘膜 IL-33 遺伝
子発現レベルが血中好酸球数と相関することから, IL-33 遺伝子が慢性症状の疾患感受性遺伝子である可 能性を見出した. また, IL-33 遺伝子発現シグナルに $\mathrm{PKC} \delta$ 及び Hsp90 が関与することを明らかにしている. このことは, $\mathrm{PKC} \delta / \mathrm{Hsp} 90$ シグナル抑制化合物が急性 症状だけでなく慢性症状も改善できる可能性を示唆す る. また, 好酸球増多により引き起こされる喘息など の疾患に対しても $\mathrm{PKC} \delta / \mathrm{Hsp} 90$ シグナル抑制は有効 であると考えられる. 現在, 野ぶどうや小青竜湯に IL-33 遺伝子発現抑制成分の存在を見出しており,こ れらの有効成分を単離し, IL-33 遺伝子発現抑制によ 


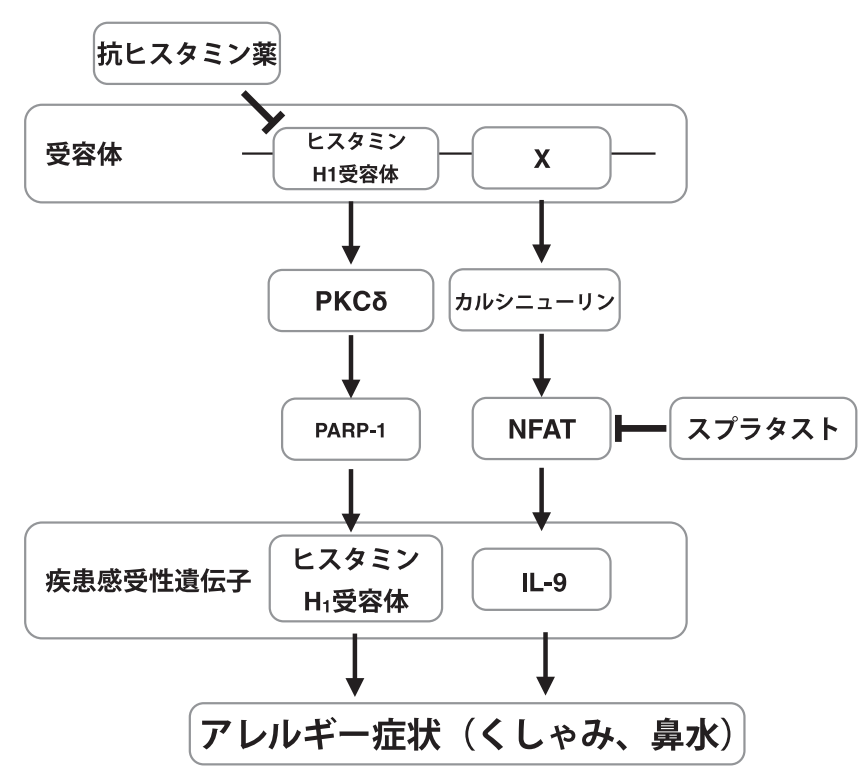

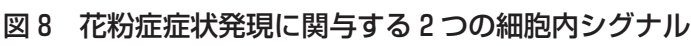

る好酸球性炎症の治療の有効性を明らかにしていきた いと考えている.さらに, $\mathrm{PKC} \delta$ シグナルや NFAT シ グナル抑制化合物は，これらのシグナルが症状発現に 関与するアレルギー疾患以外の他の疾患の治療への応 用も可能である。我々は，これまでに， $\mathrm{PKC} \delta$ シグナ ルが脺ランゲルハンス島 $\alpha$ 細胞からのグルカゴン分泌 に関与することを証明しており (20), PKC $\delta$ シグナル 抑制による糖尿病治療の有効性について証明したいと 考えている. 薬理学は単に薬物の作用機序を明らかに するだけでなく, 得られた知見を元に病態に基づいた 治療法及び治療薬の開発を行う薬物治療学でもある. 疾患感受性遺伝子に着目しその遺伝子発現細胞内シグ ナルを標的とする我々の治療戦略は多くの疾患に対し て有効であり, これらの疾患の予防や治療へ展開して いきたいと考えている.

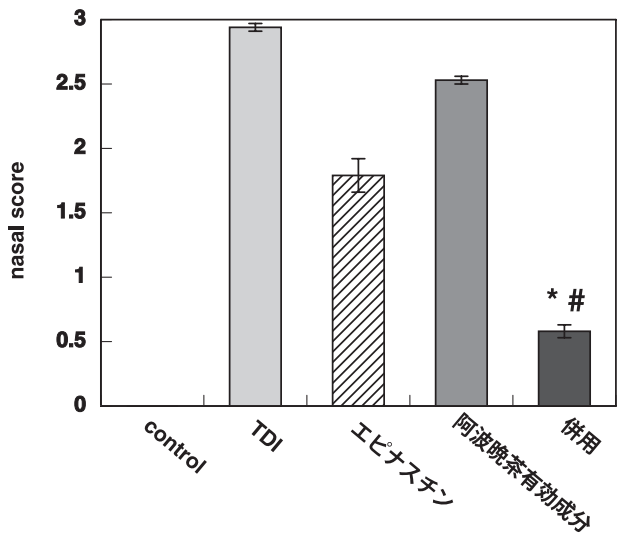

謝辞：本研究遂行に関し共同研究者の徳島大学大学院医歯 薬学研究部耳鼻咽喉科学分野武田憲昭教授, 北村嘉章講師, 並びに分子情報薬理学教室の皆様のご協力に深謝いたしま す. 本研究は文部科学省科学研究助成事業, 並びに公益財 団法人大阪難病研究財団の助成を受けて実施しました。最 後になりましたが，第 89 回日本薬理学会年会シンポジウム において発表の機会を与えていただきましたオーガナイ ザーの東北大学大学院医学系研究科機能薬理学分野谷内一 彦教授, 徳島大学医歯薬学研究部分子難病学分野福井裕行 特任教授，および本稿を作成する機会を与えていただきま した編集部の方々に心より感謝申し上げます.

著者の利益相反 : 水口博之（株式会社ニチレイバイオサイ エンス，株式会社明治，株式会社 Nab).

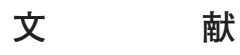

1) Mizuguchi H, et al. J Pharmacol Sci. 2009;108:480-486.

2) Das AK, et al. J Pharmacol Sci. 2007;103:374-382.

3) Mizuguchi H, et al. Yakugaku Zasshi. 2011;131:171-178.

4) Ohuchi Y, et al. Int J Mol Med. 1998;1:355-360.

5) Iriyoshi N, et al. Clin Exp Allergy. 1996;26:379-385.

6) Mizuguchi H, et al. Methods Find Exp Clin Pharmacol. 2010;32: 745-748.

7) Kitamura Y, et al. J Pharmacol Sci. 2015;129:183-187.

8) Matsushita C, et al. J Trad Med. 2008;25:133-142.

9) Hattori M, et al. Int Immunopharmacol. 2013;15:232-239.

10) Mizuguchi H, et al. Pharmacol Res Perspect. 2015;3:e00166. doi: 10.1002/prp2.166.

11) Böhl M, et al. Anal Biochem. 2005;346:295-299.

12) Nariai Y, et al. J Biol Chem. 2015;290:27393-27402.

13) Shahriar M, et al. J Immunol. 2009;183:2133-2141.

14) Mizuguchi H, et al. J Pharmacol Sci. 2016;130:151-158.

15) Schmit E, et al. Trends Immunol. 2014;35:61-68.

16) Veldhoen $M$, et al. Nat Immunol. 2008;9:1341-1346.

17) Dardalhon V, et al. Nat Immunol. 2008;9:1347-1355.

18) Mikami N, et al. J Immunol. 2013;190:4046-4055.

19) Kaibi B, et al. Brain Res. 1992;576:287-296.

20) Yamamoto K, et al. J Med Invest. 2017;64:122-128.

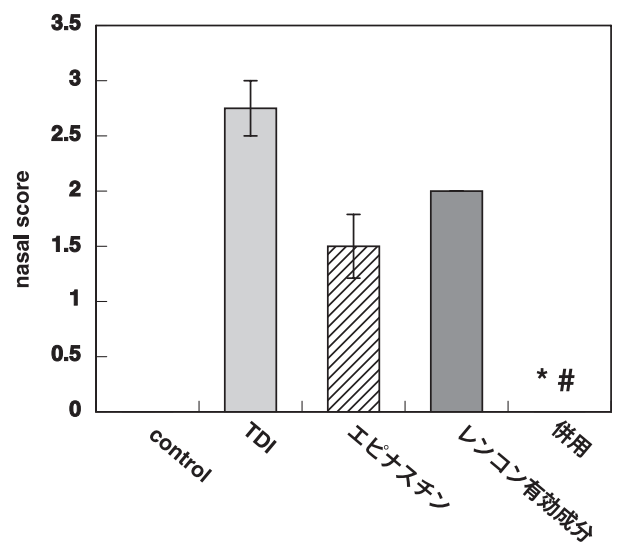

図 9 鼻過敏症モデルラットにおける天然医薬由来 IL-9 遺伝子発現シグナル抑制化合物と抗ヒスタミン薬の併用効果

阿波晚茶 (a) およびレンコン (b) 由来IL-9 遺伝子発現シグナル抑制化合物と抗ヒスタミン薬をモデルラットに併用投与したところ, それぞれ の化合物単独投与に比べ顕著な症状改善効果が認められた. デー夕は平均士S.E.M. ${ }^{*} P<0.05$ vs. TDI, ${ }^{*} P<0.05$ vs. エピナスチン ( $\mathrm{n=4).}$ 